\title{
Chlamydospore formation by Corynespora cassiicola
}

\author{
Ricardo Ribeiro Oliveira ${ }^{1}$, Bárbara de Melo Aguiar ${ }^{1}$, Dauri José Tessmann ${ }^{1}$, Valérie Pujade-Renaud ${ }^{2,3} \&$ \\ João Batista Vida ${ }^{1}$
}

${ }^{1}$ Departamento de Agronomia, Universidade Estadual de Maringá, 87020-900, Maringá, PR, Brazil; ${ }^{2}$ CIRAD, UMR AGAP, F-63000 Clermont-Ferrand, France; ${ }^{3}$ Clermont Université, Université Blaise Pascal, UMR 547 PIAF, BP 10448, F-63000, Clermont-Ferrand, France

Author for correspondence: João Batista Vida, e-mail: jbvida@uem.br

\begin{abstract}
The fungus Corynespora cassiicola is an important pathogen that causes necrotic lesions in several plant species. Saprophytism and parasitism habits of plants are common survival strategies for this pathogen. Few studies referred to the formation of chlamydospores by $C$. cassiicola. The objective of this study was to test the formation of chlamydospores by several C. cassiicola isolates from different agronomic crops and weeds. Fifteen isolates were analysed by in vivo and in vitro tests. Six isolates from four host plants (Cucumis sativus, Lantana camara, Malpighia glabra and Vernonia cinerea) were able to produce chlamydospores, both in vitro and in vivo. In vitro, chlamydospore production was highest for the Malpighia glabra isolate and one Cucumis sativus isolate, intermediate for two other C. sativus isolates, and lowest for the Vernonia cinerea and Lantana camara isolates. However, no difference in the relative number of chlamydospores produced among isolates was observed in vivo.
\end{abstract}

Key words: leaf spot, survival, target spot.

Chlamydospores are resting structures that are mainly produced by root pathogens (Machardy \& Beckman, 1981; Meronuck \& Pepper, 1968) and are an effective survival strategy in the absence of host tissue (Garrett, 1970). Furthermore, chlamydospores may be an important primary inoculum source for phytopathogenic fungi (Agrios, 2005; Amorim, 1995).

Corynespora cassiicola is a leaf pathogen from tropical and sub-tropical climates infecting more than 300 plant species (Farr \& Rossman, 2011). In Brazil, this pathogen causes serious damage on soybean (Glycine max) (Almeida et al., 2001), parthenocarpic cucumber (Cucumis sativus) (Verzignassi et al., 2003) and tomato (Lycopersicon esculentum) (Leroy \& Lourd, 1989).

In spite of the extensive research about C. cassiicola, little is known about its capacity to produce chlamydospores. Olive et al. (1945), Demidova (1962) and Sarma \& Nayudu (1971) reported the formation of chlamydospores by isolates of C. cassiicola from Vigna sinensis, C. sativus and Solanum melongena, respectively. The primary survival strategies of $C$. cassiicola are believed to be through the parasitism of host plants and saprophytic behaviour, as reported on soybean (Almeida et al., 2001), sesame (Wulff \& Pascholati, 1997), in cucurbitaceous stubble and weeds (Rêgo \& Carrijo, 2000), and in parasitizing weeds (Souza \& Silva, 2001; Cutrim \& Silva, 2003). Thus, the aim of this research was to evaluate, in vitro and in vivo, chlamydospore formation of 15 isolates of $C$. cassiicola from several host species.
The isolates of $C$. cassiicola used in this study were obtained from single-spore cultures growing on potato dextrose agar (PDA) (Table 1).

For the evaluation of the in vitro chlamydospore production, each isolate was subcultured five times in Petri dishes containing PDA, as described by Olive et al. (1945), for 20 days each time, in a heated chamber at $25 \pm 2^{\circ} \mathrm{C}$ under continuous fluorescent light. At the end of the fifth cultivation, the agar surface was scraped in the central region of each Petri dish quadrant, and a mycelium sample was obtained and analysed using an optical microscope equipped with an objective ocular micrometer to quantify and measure the chlamydospores.

For the in vivo chlamydospore production, seedlings of C. sativus, L. esculentum, Lactuca sativa, Cucurbita maxima, G. max, Lantana camara, Malpighia glabra, Pipper hispidinervium, Coleus barbatus, Commelina benghalensis and Vernonia cinerea were grown in plastic pots containing a sterilized commercial substrate (pine bark dust/vermiculite) which had been autoclaved for two periods of 1 hour at $120^{\circ} \mathrm{C}$ at intervals of 24 hours.

Seedlings were inoculated with $1 \times 10^{4}$ spores $/ \mathrm{mL}$ grown on PDA medium for 12 days. All leaves of the host plants were inoculated by atomisation of the conidia suspension onto the leaf surface (until the solution ran off the tissue) using the DeVilbiss $n^{\circ} 15$ atomiser. The plants were maintained in a humidity chamber for 48 hours at $25 \pm 2^{\circ} \mathrm{C}$ with a 12 hour photoperiod. The plant development stage at inoculation was recorded as the number of leaves present (Table 1). 
TABLE 1 - Chlamydospore formation by Corynespora cassiicola isolates from different host plants on PDA medium and on inoculated leaves of different host plants

\begin{tabular}{|c|c|c|c|c|c|c|}
\hline \multirow[t]{2}{*}{ Isolate } & \multirow[t]{2}{*}{ Host plant } & \multirow[t]{2}{*}{$\begin{array}{c}\text { Plant development stage } \\
\text { (number of leavesfully expanded) }\end{array}$} & \multicolumn{2}{|c|}{$\begin{array}{c}\text { Formation of } \\
\text { chlamydospores }\end{array}$} & \multicolumn{2}{|c|}{$\begin{array}{c}\text { Average dimension } \\
(\text { length } \mathrm{x} \text { width }[\mu \mathrm{m}])^{2}\end{array}$} \\
\hline & & & In vitro & In vivo & In vitro & In vivo \\
\hline IA & Cucumis sativus & 4 & ++ & + & $14.38 \times 12.50$ & $14.78 \times 14.22$ \\
\hline PB & Cucumis sativus & 4 & ++ & + & $15.00 \times 14.38$ & $14.65 \times 14.17$ \\
\hline JQ & Cucumis sativus & 4 & +++ & + & $13.13 \times 13.75$ & $13.56 \times 13.46$ \\
\hline LP05 & Cucurbita maxima & 4 & - & & - & - \\
\hline 493AA & Glycine $\max$ & 4 & - & & - & - \\
\hline 777AA & Glycine $\max$ & 4 & - & & - & - \\
\hline LP02 & Lycopersicon esculentum & 5 & - & & - & - \\
\hline GS01 & Carica papaya & 6 & - & & - & - \\
\hline JMP220 & Lantana camara & 8 & + & + & $13.75 \times 12.50$ & $13.64 \times 12.53$ \\
\hline LP04 & Malpighia glabra & 14 & +++ & + & $14.38 \times 13.10$ & $13.08 \times 12.67$ \\
\hline LP01 & Lactuca sativa & 10 & - & & - & - \\
\hline LP07 & Piper hispidinervium & 12 & - & & - & - \\
\hline RWB321 & Coleus barbatus & 7 & - & & - & - \\
\hline $\mathrm{CP} 03$ & Commelina benghalensis & 12 & - & & - & - \\
\hline GS02 & Vernonia cinerea & 6 & + & + & $12.50 \times 12.50$ & $13.12 \times 12.79$ \\
\hline
\end{tabular}

${ }^{1}$ Relative amount of chlamydospores: (-) chlamydospores absent, (+) up to 2 chlamydospores per field of view at 400x magnification, (++) 3 to 5 chlamydospores and (+++) 6 to 22 chlamydospores;

${ }^{2}$ Average of 40 chlamydospores from each replication.

When large necrotic lesions had formed on inoculated leaves, approximately 10 to $20 \mathrm{~mm}$ in diameter, the leaves were detached and placed in a laminar flow cabinet where they were disinfected for $1 \mathrm{~min}$ in $0.5 \%$ sodium hypochlorite. After disinfection, the leaves were placed in acrylic boxes containing two sterilised sheets of filter paper moistened with sterilised distilled water. The acrylic boxes were maintained at $24^{\circ} \mathrm{C}$ with a 12 hours photoperiod. When the fungal growth was observed on the leaves, mycelial fragments were examined under an optical microscope for the presence of chlamydospores. The relative quantity of chlamydospores and the dimensions of 40 chlamydospores from each repetition were collected for each chlamydospores producing isolate. The experiment was completely randomised, with five repetitions for each isolate. Each Petri dish (in vitro) or leaf (in vivo) was considered an experimental unit. The experiment was repeated twice.

From the fifteen isolates analysed, only six produced chlamydospores both in vivo and in vitro (Table 1). These were the three isolates from $C$. sativus and the isolates from L. camara, M. glabra, and V. cinerea.

Differences were observed among the six isolates in the amount of chlamydospores formed in vitro. One isolate from $C$. sativus (JQ) produced a high quantity of chlamydospores, while the other two (IA and PB) had a medium production, under the same conditions. The isolates from $L$. camara and $V$. cinerea produced a low amount of chlamydospores. The isolate from M. glabra produced a high quantity of chlamydospores, comparable to that of the C. sativus isolate JQ (Table 1).
In vivo, mycelium growth occurred on the surface of the leaf lesions of all the host plants inoculated with C. cassiicola after five days of incubation in the humidity chamber. However, only the six isolates mentioned above developed chlamydospores. By comparing the in vivo and in vitro conditions, it appeared that the PDA growth medium was more favourable for chlamydospore production than the host leaf tissue. The relative abundance of chlamydospores produced in vivo was low and similar for all six isolates (Table 1).

The average dimensions of the chlamydospores observed in vitro were $13.86 \mu \mathrm{m}$ in length and $13.12 \mu \mathrm{m}$ in width. The largest chlamydospore size was found for the PB (C. sativus) isolate $(15.00 \mu \mathrm{m} \times 14.38 \mu \mathrm{m})$, and the smallest was observed for the GS02 ( $V$. cinerea) isolate $(12.50$ $\mu \mathrm{m} \times 12.50 \mu \mathrm{m})($ Table 1$)$. We found that chlamydospore formation in vitro occurred in three possible forms: terminal, intercalary or chains of up to five chlamydospores (Figure 1), regardless of the isolate. Chlamydospores produced in vivo exhibited similar dimensions; however, in contrast to the results obtained under in vitro, only terminal and intercalary chlamydospores were observed (Figure 1 A, B and C).

In the literature, there are only two reports regarding chlamydospores formation by $C$. cassiicola in vivo (Demidova, 1962; Sarma \& Nayudu, 1971). The authors reported the importance of this structure to survival of the fungus in plant debris. Chlamydospores were also observed by Olive et al. (1945) in old cultures from successive transfers. Here we present evidence of chlamydospore formation by C. cassiicola in in vivo and in vitro tests, using several isolates and plant hosts. We suggest that the 

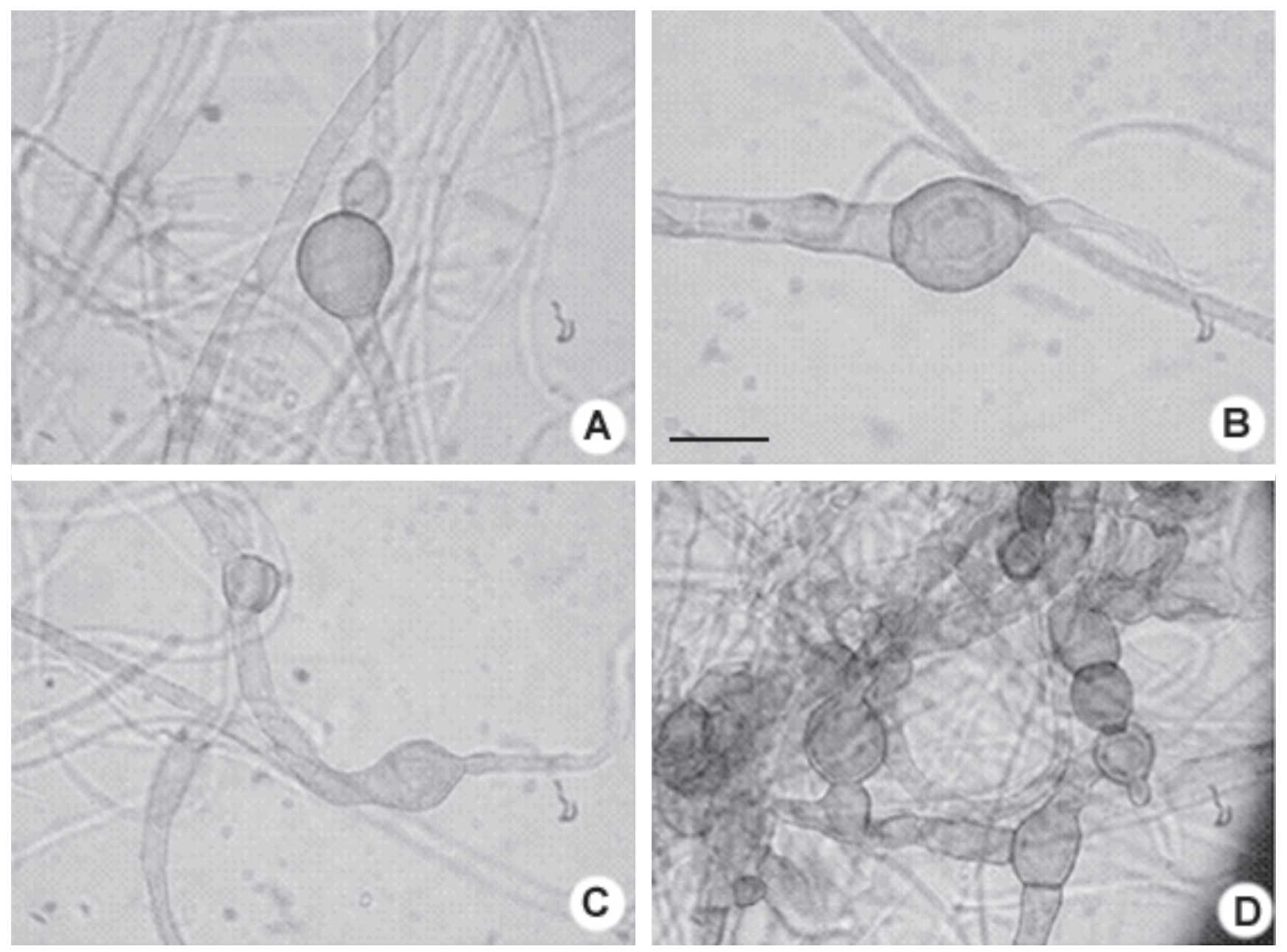

FIGURE 1 - Chlamydospores formed in vitro and in vivo: A. terminal formation; B and C. intercalary formations; D. chain formations. Scale bar for $\mathrm{B}=10 \mu \mathrm{m}$.

chlamydospores of $C$. cassiicola produced in vivo may contribute as an important source of primary inoculum.

Chlamydospores allow the fungi to survive in soil or plant debris. Meronuck \& Peper (1968) reported the formation of chlamydospores among Bipolaris sorokiniana conidia. Chinn (1976) showed that these structures may be the survival forms of this pathogen in the soil. Although $C$. cassiicola is mostly known as a pathogen infesting the aerial portions of the plant, the observation of chlamydospores suggests that this fungus may also have the capacity to survive in the absence of a living host, or under unfavourable conditions. The importance of chlamydospores as a primary inoculum source for $C$. cassiicola will have to be further investigated.

\section{ACKNOWLEDGEMENTS}

The authors wish to thank Coordenação de Aperfeiçoamento de Pessoal de Nível Superior - CAPES for granting a scholarship to R.R. Oliveira and B.M. Aguiar.

\section{REFERENCES}

Agrios GN (2005) Plant Pathology. $5^{\text {th }}$ Ed. San Diego CA. Elsevier Academic Press.

Almeida AMR, Saraiva OF, Farias JRB, Gaudêncio CA, Torres E (2001) Survival of pathogens on soybean debris under notillage and conventional tillage systems. Pesquisa Agropecuária Brasileira 36:1231-1238.

Amorim L (1995) Sobrevivência do inóculo. In: Bergamin Filho A, Kimati H, Amorim L (Eds.) Manual de Fitopatologia - Princípios e conceitos. São Paulo SP. Agronômica Ceres. pp. 246-267.

Chinn SHF (1976) Influence of rape in a rotation on prevalence of Cochliobolus sativus conidia and common root rot. Canadian Journal Plant Science 56:199-201.

Cutrim FA, Silva GS (2003) Patogenicidade de Corynespora cassiicola a diferentes espécies de plantas. Fitopatologia Brasileira 28:193-194.

Demidova L (1962) Some problems of biology of fugus C. cassiicola, the causal agent of black mold of cucumber. Zap. Leningr. sel. skohkoz. Inst. Mem. Inst. agron. Leningrad 87:91-95. 
Farr DF, Rossman AY (2011) Fungal Databases. Systematic Mycology and Microbiology Laboratory, ARS/USDA. Available at: http://nt.ars-grin.gov/fungaldatabases/ Accessed on December 5, 2011.

Garrett SD (1970) Pathogenic root-infecting fungi. Cambridge/ London UK. Cambridge University Press.

Leroy M, Lourd M (1989) Doença foliar do tomateiro causada por Corynespora cassiicola em Manaus. Fitopatologia Brasileira 14:32-36.

Machardy WE, Beckman CH (1981) Vascular wilt Fusaria: infection and pathogenesis. In: Nelson PE, Tousson TA, Cook RJ (Eds.) Fusarium: Diseases, Biology and Taxonomy. London UK. Pennsylvania University Press. pp. 365-390.

Meronuck RA, Pepper EH (1968) Chlamydospore formation in conidia of Helminthosporium sativum. Phytopathology 58:866867.

Olive LS, Bain DC, Lefebvre CL (1945) A leaf spot of cowpea and soybean caused by undescribed species of Helminthosporium.
Phytopathology 35:822-831.

Rêgo AM, Carrijo IV (2000) Doenças das cucurbitáceas. In: Zambolim L, Vale FXR, Costa H (Eds.) Controle de doenças de plantas - hortaliças. Viçosa MG. Suprema Gráfica e Editora Ltda. pp. 535-598.

Sarma Y, Nayudu M (1971) Corynespora leaf spot of brinjal. Proceedings of the Indian Academy of Sciences - Section B 74:9297.

Souza IMR, Silva GS (2001) Fungos associados a plantas daninhas na ilha de São Luiz, Maranhão. Summa Phytopathologica 27:266268.

Verzignassi JR, Vida JB, Tessmam DJ (2003) Corynespora cassiicola causando epidemias de manchas foliares em pepino "japonês" sob estufa no Norte do Paraná. Fitopatologia Brasileira 28:570.

Wulff NA, Pascholati SF (1997) Doenças do Gergelim. In: Kimati H, Amorim L, Bergamin Filho A, Camargo LEA, Rezende JAM (Eds.) Manual de Fitopatologia - doenças das plantas cultivadas. São Paulo SP. Agronômica Ceres. pp. 427-435. 